\title{
IMPLEMENTASI UNDANG-UNDANG NOMOR 2 TAHUN 2014 TENTANG JABATAN NOTARIS DALAM PEMBUATAN AKTA PENDIRIAN BADAN USAHA MILIK DESA DI KABUPATEN TEGAL
}

\author{
Putri Wulansari, Fifiana Wisnaeni \\ Program Studi Magister Kenotariatan, \\ Fakultas Hukum, Universitas Diponegoro \\ Email:wulansari@gmail.com
}

\begin{abstract}
Village Owned Enterprises or hereinafter abbreviated to BUMDes is a product of Act number 6 of 2014 about Village. The research in this thesis discusses problem of how the implementation of Law No. 2 of 2014 on the position of Notary in the making of the deed of establishment of BUMDes in Tegal Regency and what are the obstacles in the implementation of this. The method used in this research is empirical juridical with analytical descriptive research specification. The result of the research shows that the implementation of law number 2 year 2014 about the position of Notary in making the deed of establishment of BUMDes in Tegal Regency has not been implemented well, because BUMDes in Tegal Regency is still very new and still few in number, but BUMDes is not yet have a deed of incorporation of a business entity conducted in the presence of Notary. This happens because they do not know the benefits they get, they claim that the process of making the deed of establishment requires sufficient time long and costly.
\end{abstract}

Keywords: Village Owned Enterprise (BUMDes), Notary Public, Deed of Establishment

\begin{abstract}
Abstrak
Badan Usaha Milik Desa atau yang selanjutnya dapat disingkat dengan BUMDes merupakan produk dari Undang-undang Nomor 6 Tahun 2014 tentang Desa. Penelitian dalam tesis ini membahas permasalahan mengenai bagaimana implementasi Undang-undang Nomor 2 Tahun 2014 tentang Jabatan Notaris dalam pembuatan akta pendirian BUMDes di Kabupaten Tegal serta apa kendala dalam implementasi tersebut. Metode yang digunakan dalam penelitian ini adalah yuridis empiris dengan spesifikasi penelitian deskriptif analitis. Hasil penelitian menunjukkan bahwa implementasi belum dilaksanakan dengan baik, karena masih terbilang sangat baru dan masih sedikit jumlahnya, tetapi BUMDes tersebut belum ada yang memiliki akta pendirian badan usaha yang dilakukan di hadapan Notaris, karena mereka belum mengetahui keuntungan yang diperoleh dan proses pembuatan akta pendirian memerlukan waktu yang cukup lama dan membutuhkan biaya yang tidak sedikit.
\end{abstract}

Kata Kunci : Badan Usaha Milik Desa (BUMDes), Notaris, Akta Pendirian

\section{A. Pendahuluan}

Pembangunan nasional adalah suatu usaha yang dilakukan untuk meningkatkan seluruh aspek kehidupan masyarakat, bangsa, dan Negara. Adapun tujuan dari pembangunan adalah untuk membangun kemandirian, termasuk pembangunan pedesaan. Sebagian besar penduduk 
Bangsa Indonesia sendiri hidup di kawasan pedesaan. Oleh karena itu, titik sentral pembangunan adalah daerah pedesaan. Desa menurut Widjaya adalah sebagai kesatuan masyarakat hukum yang mempunyai susunan asli berdasarkan hak asal-usul yang bersifat istimewa (Widjaya, 2003).

Indonesia sebagai negara kesatuan yang menganut asas otonomi, dalam rangka melaksanakan otonomi dan mengupayakan pengembangan Desa serta peningkatan ekonomi Desa maka dibentuklah Badan Usaha Milik Desa sebagai badan usaha yang bercirikan Desa (Irawati \& Budiharto \& Mahmudah, 2016).

Salah satu pengemban profesi hukum ialah Notaris sebagai pejabat umum yang berwenang untuk membuat akta autentik dan memiliki kewenangan lainnya yang diatur dalam Undang-Undang Jabatan Notaris. Gerak perputaran roda pembangunan nasional yang semakin kompleks dewasa ini menuntut peran Notaris, khususnya sebagian kewenangan pemerintah yang dilimpahkan kepada Notaris dalam bidang keperdataan, seperti pembuatan akta, pengurusan izin perusahaan dan lain sebagainya (Mariyam, 2015).

\section{B. Metode Penelitian}

Metode penelitian yang digunakan adalah yuridis empiris, dengan spesifikasi penelitiannya secara deskriptif analitis. Teknik analisa datanya menggunakan analisis kualitatif dengan pemikiran indukatif.

\section{Hasil dan Pembahasan}

\section{Implementasi Undang-Undang Nomor 2 Tahun 2014 Tentang Jabatan Notaris Dalam Pembuatan Akta Pendirian BUMDesa Di Kabupaten Tegal}

Notaris dalam pelaksanaan BUMDesa memiliki peran yang sangat signifikan. Dalam Pasal 1 angka 1 Undang-undang Jabatan Notaris, Notaris adalah pejabat umum yang berwenang untuk membuat akta otentik dan kewenangan lainnya sebagaimana dimaksud dalam Undang-Undang Jabatan Notaris ini merujuk pada tugas dan wewenang yang dijalankan oleh Notaris. Artinya, Notaris sebagai pejabat umum memiliki wewenang untuk membuat akta otentik serta kewenangan lainnya yang diatur oleh Undang-undang Jabatan Notaris.

Pembuatan akta otentik di hadapan Notaris, bukan saja karena diharuskan oleh peraturan perundang-undangan, tetapi juga karena dikehendaki oleh pihak yang berkepentingan demi kepastian hak dan kewajiban para pihak yang berkepentingan sekaligus bagi masyarakat secara keseluruhan. Dari ketentuan yang dinyatakan dalam Pasal 
1 Undang-Undang Jabatan Notaris dan Pasal 1868 Kitab Undang-Undang Hukum Perdata dapat disimpulkan bahwa Notaris adalah pejabat umum yang diberi kewenangan oleh Negara untuk membuat suatu akta otentik, kecuali yang dikecualikan kepada pejabat atau orang lain. Maka, dapat dijelaskan peranan Notaris dalam BUMDesa antara lain, yaitu:

1) Membuat akta pendirian unit usaha BUMDesa yg berbadan hukum, berupa Perseroan Terbatas \& Lembaga Keuanga Mikro;

2) Membuat perjanjian kerjasama antar BUMDesa bila dikehendaki dalam bentuk akta Notaris;

3) Membuat perjanjian kerjasama antara BUMDesa dg pihak ketiga lainnya bila dikehendaki dlm bentuk akta Notaris;

4) Membuat berita acara rapat-rapat dalam BUMDesa bila dikehendaki dalam bentuk akta Notaris;

5) Membuat akta Notaris yg terkait dengan kegiatan usaha BUMDesa maupun unit-unit usaha BUMDesa yg berbentuk badan hukum maupun badan usaha non badan hukum;

6) Membuat akta Notaris yg di kehendaki pihak yg berkepentongan dlm BUMDesa dan lain lain yang tidak melanggar peraturan perundang-undangan yang berlaku.

Penulis mengambil beberapa sampel untuk dijadikan subjek dalam penelitian yaitu BUMDesa Harapan Masyarakat milik Desa Kendal Serut, BUMDesa Mergo Amanah milik Desa Prupuk Selatan, BUMDesa Bangun Artha Sejahtera milik Desa Marga Ayu, dan BUMDesa Subur Makmur milik Desa Kepunduhan.

Beberapa dasar hukum pembentukan Badan Usaha Milik Desa terdapat di dalam beberapa peraturan sebagai berikut (Khairandy, 2016):

a. Pasal 213 UU No 32 Tahun 2004 tentang Pemerintahan Daerah

b. Pasal 87 sampai dengan Pasal 90 UU No 6 Tahun 2014 tentang Desa

c. Pasal 132 sampai dengan Pasal 142 PP No 43 Tahun 2014 tentang Peraturan Pelaksana UU No 6 Tahun 2014 tentang Desa

d. Pasal 142 PP No 47 Tahun 2015 tentang Perubahan atas PP No 43 Tahun 2014 tentang Peraturan Pelaksana UU No 6 Tahun 2014 tentang Desa

e. Permendes PDTT No 4 Tahun 2015 tentang Pendirian, Pengurusan, dan Pengelolaan dan Pembubaran Badan Usaha Milik Desa

Tidak dapat dipungkiri, jika pengelolaan BUMDesa harus dilakukan secara hukum, profesional, dan mandiri. Dari sisi hukum, legalitas akta notaris dalam BUMDesa adalah di 
dalam AD/ART BUMDesa. Selain itu, dalam Pasal 7 dan Pasal 8 BUMDesa dapat membentuk unit-unit usaha yang berbadan hukum yang jelas harus memiliki akta Notaris. Kerjasama adalah hal yang pasti terjadi di dalam BUMDesa, maka legalitas ini perlu yang merupakan syarat yang harus dipenuhi. Karena segala bentuk kerjasama dan hubungan hukum memerlukan jaminan dari status hukum badan tersebut. Dengan adanya status hukum itu, maka akan memberikan kepercayaan bagi siapa saja yang akan bekerjasama dengan BUMDesa.

Hal-hal tersebut berkaitan dengan teori sistem hukum menurut Lawrence M. Friedman yang menyatakan bahwa setiap sistem hukum mengandung 3 (tiga) komponen, yaitu :

1) Struktur Hukum

Struktur hukum merupakan kerangka dari suatu sistem hukum, misalnya pengorganisasian kelembagaannya, batas-batas kewenangannya dan jalinan kerjasama antar aparat penegak hukum. Terkiat dengan struktur hukumnya, BUMDesa telah memenuhi karena di dalam BUMDesa memiliki organisasi. Hal tersebut bisa dilihat dalam Peraturan perundang-undangan yang menyebutkan mengenai organisasi yang dimiliki BUMDesa yaitu dalam Pasal 9 sampai dengan Pasal 16 Permendes PDTT No 4 Tahun 2015.

2) Substansi Hukum

BUMDesa telah memenuhi unsur substansi hukum baik yang kaidah substansial maupun kaidah prosedural. Dalam kaidah prosedural bisa dilihat bahwa pendirian desa di kukuhkan dengan peraturan desa mengenai BUMDesa, yang mana di dalam peraturan desa tersebut telah di atur mengenai tugas dan wewenang masing-masing pemegang organisasi seperti komisaris, pengurus dan pengawas, dalam peraturan desa juga diatur mengenai bagaimana cara melakukan kerjasama atau hubungan keluar dengan pihak ketiga. Sedangkan yang berkaitan dengan kaidah substansial bisa dilihat dari dengan dikeluarkannya peraturan-peraturan mengenai pendirian BUMDesa, maka anggota masyarakat harus menindak lanjuti hal tersebut dengan membentuk BUMDesa di desa mereka.

3) Kultur Hukum

Berkaitan dengan kultur hukum ini, setelah dilakukan adanya studi dilapangan, bahwa kehadiran BUMDesa di tengah masyarakat pedesaan di sambut secara positif bahkan masyarakat sekitar ikut berpartisipasi dalam menjalankan segala kegiatan unit 
usaha yang di disediakan oleh BUMDesa. Bahkan dengan hadirnya BUMDesa menjadikan masyarakat menjadi lebih mandiri.

\section{Kendala Dalam Implementasi Undang- Undang Nomor 2 Tahun 2014 Tentang Jabatan} Notaris Dalam Pembuatan Akta Pendirian BUMDesa Di Kabupaten Tegal

Pendirian BUMDesa memang ditetapkan dengan Peraturan Desa hasil dari Musyawarah Desa. Meskipun demikian, Peraturan Desa tersebut dan juga AD/ART BUMDesa dapat ditetapkan dengan akta pendirian dihadapan Notaris agar supaya legalitas mereka benar-benar dijamin oleh Negara dan BUMDesa memperoleh kepercayaan dari pihak lain. Akan tetapi, hal ini belum begitu dipahami oleh masyarakat Kabupaten Tegal, khususnya bagi BUMDesaBUMDesa yang telah berdiri.

Kurangnya informasi mengenai keuntungan yang akan di dapat bila BUMDesa menjadi sebuah badan hukum dengan dikukuhkan menggunakan Akta pendirian Notaris menjadikan para pengurus organisasi BUMDesa tidak melanjuti proses tersebut.

Pengurus BUMDesa menyatakan biaya yang dikeluarkan untuk mengurus akta pendirian BUMDesa tidak sedikit, belum lagi banyak persyaratan yang harus dipenuhi untuk mengajukan akta pendirian BUMDesa serta proses pembuatan akta pendirian yang memakan waktu lama menjadikan kami enggan untuk membuat akta pendirian BUMDesa dihadapan Notaris. Akan tetapi, beliau juga menambahkan bahwa BUMDesa ini nantinya ingin dikukuhkan dengan akta pendirian Notaris agar supaya keberadaannya lebih diakui.

BUMDesa yang akan membentuk Perseroan Terbatas sebagai suatu badan usaha memiliki kelebihan maupun kekurangan. Secara sederhana, kelebihan atau keuntungan bentuk perseroan terbatas adalah sebagai berikut :

a. Adanya kepastian hukum menimbulkan dampak positif terkait kelangsungan perseroan, pengelolaan perseroan, dan tanggung jawab perseroan.

b. Memudahkan investor dalam memindahkan hak milik atas perseroan dengan cara menjual saham dari perseroan tersebut kepada investor lainnya.

c. Dalam memperoleh tambahan modal, PT tergolong mudah karena sistem pengelolaan perseroan yang unik sehingga lebih mudah dalam memperluas volume usaha.

d. Mengurangi potensi beban para pemegang saham terkait pembayaran hutang, karena tanggung jawab untuk melunasi hutang hanya terbatas pada kekayaan perseroan saja.

Beberapa kelemahan yang dimiliki oleh PT dan banyaknya syarat administratif yang diperlukan untuk menjadi PT, menjadikan BUMDesa-BUMDesa yang ada di Kabupaten 
Tegal masih enggan untuk menindaklanjuti hal tersebut. Belum lagi BUMDesa tersebut baru saja merintis beberapa unit usaha yang dimilikinya, dengan umurnya yang masih seumur jagung, mereka belum berani mengambil resiko yang besar menjadi BUMDesa menjadi PT. Akan tetapi bila di masa yang akan mendatang, mereka mendapat banyak keuntungan yang diperoleh dari BUMDesa tersebut, maka tidak menutup kemungkinan mereka akan berniat untuk mengembangkannya menjadi PT.

Akta Pendirian BUMDesa yang dilakukan dihadapan Notaris harus ditindak lanjuti jika memang BUMDesa-BUMDesa ini akan menjadi sebuah Perseroan Terbatas dan Lembaga Keuangan Mikro. Karena untuk menjadi suatu badan hukum PT dan LKM yang diakui menurut Undang-undang PT dan Undang-undang LKM, maka mau tidak mau mereka harus membuat akta pendirian yang dilakukan di hadapan Notaris. Pendirian suatu PT maupun LKM tersebut harus dengan akta Notaris yang dibuat dengan bahasa Indonesia.

Munculnya kendala yang ada di masyarakat berkaitan dengan teori sistem hukum M. Lawrence Friedman mengenai kultur hukum. Bahwa Kultur Hukum merupakan keseluruhan dari sikap-sikap warga masyarakat yang bersifat umum dan nilai-nilai dalam masyarakat yang akan menentukan bagaimana seharusnya hukum itu berlaku dalam masyarakat. Kurangnya informasi yang diperoleh oleh masyarakat menjadi proyeksi bahwa pemerintah tidak secara maksimal dalam melakukan sosialisasi dan himbauan kepada masyarakat. Sehingga, banyak ditemukan di lapangan hal-hal yang bertentangan dengan undang-undang yang berlaku. Misalnya, sudah sangat jelas bahwa dikatakan bila BUMDesa mendirikan LKM (Lembaga Keuangan Mikro) diperlukan adanya akta pendirian Notaris, akan tetapi masih banyak sekali LKM di Indonesia, di Kabupaten Tegal misalnya yang belum menggunakan akta Notaris dalam pendirian LKM tersebut.

Ketidaktegasan pemerintah dalam hal pengaturan BUMDesa berkaitan dengan substansi hukum dalam teori sistem hukum. BUMDesa jelas tidak dapat dipersamakan dengan Perseroan Terbatas maupun Koperasi, maka dari itu seharusnya legalitas mengenai status badan hukum yang tertera pada BUMDesa sebaiknya diperbaiki. Karena pendirian Perseroan Terbatas dan Koperasi serta Lembaga Keuangan Mikro membutuhkan akta pendirian yang dibuat dihadapan Notaris, akan tetapi di dalam pengaturan mengenai pendirian dan pembentukan BUMDesa dinyatakan bahwa BUMDesa dibuat berdasarkan Musyawarah Desa dan ditetapkan dengan Peraturan Desa, tidak ada aturan mengenai harus dibuat dengan akta 
Notaris. Maka, dilihat dari hal tersebut, dapat dikatakan bahwa substansi hukum mengenai BUMDesa tidak berjalan dengan baik.

Struktur hukum dalam hal kendala disini berkaitan dengan bagaimana jalinan kerjasama antar aparat penegak hukum. Dalam hal ini, perwujudannya dapat dilihat dari banyaknya desa-desa yang belum memahami potensi desa yang ada di desanya, dan juga pemerintah desa tersebut tidak secara aktif dalam pelaksanaan pemerintahannya. Banyak juga desa-desa yang belum berani mengambil langkah untuk menjalankan unit usaha yang telah mereka tuangkan dalam rancangan BUMDesa milik mereka. Maka, dapat dikatakan jalinan kerjasama disini tidak berjalan dengan baik.

\section{Simpulan}

1. Implementasi Undang-Undang Nomor 2 Tahun 2014 tentang Jabatan Notaris Dalam Pembuatan Akta Pendirian BUMDesa di Kabupaten Tegal belum dapat dilaksanakan dengan hasil yang baik. Undang-Undang Nomor 6 tahun 2014 mengenai Desa yang menghasilkan produk BUMDesa ini memang tidak ada aturan yang mewajibkan untuk pendirian BUMDesa dengan menggunakan akta Notaris. Akan tetapi, BUMDesa ini tidak dapat disamakan dengan badan usaha lain seperti PT dan Koperasi yang statusnya jelas berbadan hukum, karena dalam peraturan yang mengatur mengenai keduanya membutuhkan akta notaris sebagai syarat dalam pendirian untuk memperoleh status badan hukum yang diakui oleh Negara. Dari sejumlah Badan Usaha yang ada di Kabupaten Tegal sendiri belum ada yang memiliki unit usaha yang menggunakan akta Notaris dalam pendirian BUMDesa. Meskipun terdapat unit usaha Lembaga Keuangan Mikro di BUMDesa mereka, akan tetapi LKM tersebut belum memiliki akta Notaris dalam pendiriannya.

2. Implementasi aturan ini kurang berjalan dengan baik di BUMDesa Kabupaten Tegal karena ada beberapa kendala. Kendala tersebut terjadi karena kurangnya informasi yang diperoleh oleh masyarakat mengenai pentingnya suatu badan usaha yang memiliki status badan hukum yang akta pendiriannya dibuat dihadapan Notaris, dan juga panjangnya proses yang harus dilalui oleh BUMDesa jika ingin menjadikan unit usahanya menjadi badan hukum seperti Perseroan Terbatas maupun Lembaga Keuangan Mikro serta mahalnya biaya yang harus mereka keluarkan untuk menjadikan unit usaha mereka berbadan hukum yang memiliki akta Notaris menjadikan mereka belum ingin untuk menindaklanjuti unit usaha mereka dengan akta Notaris. 


\section{DAFTAR PUSTAKA}

Abdulkadir, Muhammad. 2004. Hukum dan Penelitian Hukum. Bandung: Citra Aditya Bakti. H.A.W, Widjaya. 2003. Otonomi Desa : Merupakan Otonomi yang Asli, Bulat dan Utuh. Jakarta: Raja Grafindo Persada.

Irawati, Budiharto, Siti Mahmudah. 2016. Tanggung Jawab Pengurus dalam Pelaksanaan Prinsip GCG (Good Corporate Governance) pada BUMDesa (Badan Usaha Milik Desa). Diponegoro Law Journal Vo.5, No.4, 2016

Ridwan, Khairandy. 2016. Karakteristik Badan Usaha Milik Desa. Makalah disajikan dalam Seminar Nasional Peran Notaris dalam Pendirian BUM Desa Kajian Terhadap Aspek Hukum BUM Desa dan Implementasinya dalam Akta Notaris, Universitas Islam Indonesia. Yogyakarta, 19 Maret 2016.

Yulies Tiena Masriani, Haryati dan Siti Mariyam. Membangun Model Ideal Pengawasan Notaris. Jurnal Masalah-Masalah Hukum:Oktober 2015, Jilid 44 Nomor 4. 